\title{
Detecting Earning Management and Earning Manipulation in BRIC Countries; a Panel Data Analysis for Post Global Financial Crisis Period
}

\section{Ahmed Shahzad*}

School of accounting and finance, The University of Lahore, Lahore City Campus, Lahore, Pakistan

\begin{abstract}
The financial statement tells us a story, on this how much we can trust on it. This issue represents Earning Quality, covers two things one is earning management and second is earning manipulation. The objective of this study is to measurement the earning quality in BRIC countries; companies to what extent represents financial statements are trusted worthy for their stakeholders.

In this study, the discretionary accruals are used as a proxy of earning manipulation and nondiscretionary accrual serves as a proxy of earning management. Data collection is taken from the BRIC countries companies' annual reports. Modified Jones model (cross-sectional) is applied to estimate the earning management and earning manipulation for each country.

The author finds strong evidence about BRIC countries involve in earning management and earning manipulation.

In Case of Russia, model could not be able to detect the significant earning manipulation; one reason behind this issue is that Russian company's data collection are very limited and do not follow the IASB or GAAP rather they follow own country GAAPs.

This research would be helpful for the auditor, the user of financial statement and accounting standard bodies like IASB or GAAPs that they should reduce the role of discretionary accruals.

The authors extend previously modified Jones model and apply it to BRIC countries. The authors also extend previous work by determining the characteristics of firms which manage their earnings.
\end{abstract}

Keywords: Earning Quality; Earning management; Earning manipulation; Discretionary accrual; Non-discretionary accruals; Director discretions; Total accruals; BRIC countries

\section{Introduction}

This article explains the method of detecting the earning management and earning manipulation, also, credence the common ways and motives behind the earning- management and earning manipulation made by the companies to gain fake public recognition and deceives their stakeholders. Despite stricter accounting rules and standard like GAAP and IAS, these schemes happened especially after the Enron scheme the accounting profession came under the critics. Former chief of SEC Levitt [1], used the term "The Number Game" that how companies manipulated their income statement to achieve certain targets. Schipper [2], explained that earning-management is a purposeful intervention in the external financial reporting process, which objective is to achieve certain Gains. The only disadvantage behind accrual base accounting is that it lends itself to management discretion in matching which causes the possibility of earning manipulation. Management can be used their discretions in reporting the financial statements are: Revenue recognition and Expenses Recognition, Revenue Recognition: where company may change the revenue picture or smooth for a period by booking sale too early, too late.

The problem occurs due to the misuse of flexibility in the discretions of directors. Consequently, this, distort the true picture of financial statements of the companies. Eining et al. [3], explained that most common type of fraud is made through premature and factious recognition of revenue. Bonner et al. [4], investigated that accounting fraud involves fractious transactions and higher litigation against auditors. Marinakis [5], investigated that both earning management and accounting fraud involve common component which is manipulation of financial information through earning manipulation for achieving certain results.
The sharp line difference between earning management and earning manipulation is explained by Dechow et al. [6], accounting practices that violate the GAAP and IAS are called earning manipulation and fraudulent accounting. Moreover, if management uses their discretions which do not violate the GAAP or IFRS then it is called earning management.

Rosner R.L [7] coined the term earning manipulations which cover both terms earning manipulation and fraudulent accounting. It has been furthermore investigating that" accounts" involved in estimation like "Discretionary accruals" can either be postulated as earning management or fraudulent accounting. In a nutshell result, it's all upon the size of dispute amount, it has been concluded that "materiality" is the common factor among them. Because "material earning overstatement" comes under the classification of fraud. Wahlen JM [8] earning management is invoking with the help of classifications like shifting of core expenses to non-recurring items. Athanasakou VE et al. [9] the aggressive use of discretionary accrual causes earning manipulation.

This study contributes to the existing literature in different ways; perhaps this aspect has been discussing in detail with the previous studies, now a researcher has unleashed their work from previous

*Corresponding author: Shahzad A, School of accounting and finance, The University of Lahore, Lahore City Campus: 47/C3, Gulberg III-Lahore, Pakistan, Tel: 9203214054320; E-mail: greataryan786@gmail.com

Received May 02, 2016; Accepted June 09, 2016; Published June 14, 2016

Citation: Shahzad A (2016) Detecting Earning Management and Earning Manipulation in BRIC Countries; a Panel Data Analysis for Post Global Financial Crisis Period. Int J Account Res 4: 134. doi:10.4172/2472-114X.1000134

Copyright: @ 2016 Shahzad A. This is an open-access article distributed unde the terms of the Creative Commons Attribution License, which permits unrestricted use, distribution, and reproduction in any medium, provided the original author and source are credited. 
research by applying the model to BRIC countries. Researcher pertains categorically the difference between earning management and earning manipulation in their model.

In the existing literature, there are many fraternal models exist to detect the earning quality but in this study we have developed a systematic model, gives credence on the basis of the strong conceptual framework, which can detect the earning management and earning manipulation of BRIC countries. Moreover studies suggested that firm of BRIC countries are still involved in earning-management and earning manipulation even after the financial crisis of 2007.

The objective of this study is to develop a model which can produce the credence of earning management and earning manipulation in the BRIC countries. In the earlier research, no one has conducted the research on BRIC countries despite all others likely factors which enhance the importance of BRIC countries. In the coming era land resource base country will be gain attention towards the research, thus for researcher chose the unit of analysis BRIC countries. The second objective of this study provides the guideline to regulators like accounting standards bodies about the critical view on all financial statements that how much it is realistic and gives a true and fair view to stakeholders. We acknowledge that topic of earning quality is very complex and our conjecture needs to be examined in more detail by future research.

The practical implementation of this study provide a sound model to the investor and regulated accounting bodies like security exchange commission and IAS or IFRS board to find out, about financial statements how much realistic and gives a true and fair view of the investor and regulated bodies concern how to evaluate the accounting standards which can reduce the directors discretion. In this concern research question has been generated to get the answer of these problems, whereas hypotheses are generated only in the econometrics model development.

For the development of the econometric model which can measure the earning quality in BRIC countries several approaches is promulgated but total accrual, measurement approach uses through cash flow approaches due to non-articulation issues. Modified Jones' model to estimate the discretionary and nondiscretionary accrual, cross-sectional analysis applied. This model has two stages. Thus, the result of first part of the analysis will plug into next stage to get the estimates which we needed. First stage model-1 is used to estimate each year using ordinary least squares estimation. Therefore, that accrual represents no business reason to generate this accrual.

Thus, for discretionary accrual consider batter proxy for earning management. Model parameters have emerged specific digits which can be helpful in applying regression equation.

At the end, this study has four-fold, in section 2 we review the literature with strong theoretical background and section 3 develop research design and section 4 draw out the empirical results and in the last section 5 present the conclusion and summary of the study.

\section{Literature Review and Research Questions}

In this area researcher has discussed the research gap, and this literature relates to research questions. The major gap is no one has applied earning quality model on BRIC countries.

\section{GAAP and IFRS granted discretions to management}

According to GAAP and IFRS, companies are allowed to realize certain items on the discretions of the management like to recognition of revenue and handled extraordinary income and expenses. Most of the companies freely admit earning-management due to adding stability in the stock price.

\section{The Role of auditor in detection of earning management}

We cannot ignore the role of the auditor in the detection of earning management. The behavior of the auditor demands professional skepticism." auditor is watched dog, not a bloodhound" Auditor should not make perception in advance about the misconception with the management. The Auditor Responsibility to consider fraud in an Audit of financial statements. (ISA 240: Para, 30). Fraudulent financial reporting involves intentional misstatements or omission of amounts or disclosure in financial statements to deceive financial statement users (IFAC 2004, par.8). Whereas, in acceptable or unacceptable accounting practice beyond the line the auditor has a professional and legal responsibility to confront those charges with management, (ISA 240).

The role of tire 1 audit firms: Hodge FD [10] find that investor has a great decline in the reliability of the financial statements which are audited by auditors. Further studies revealed that Big 4 audit firms (tier 1 accounting firms) are performing greater reporting conservatism than auditors employed by other accounting firms.

Karamanou I et al. [11] find that tier 1 audit firm's auditors have greater skills and professional skepticism than other audit firms, which really put a greater constraint on earning management.

\section{Accounting fraud and earning management}

Accounting fraud involves the following items like employee fraud, payroll fraud bribery, kickbacks and insider trading and intentional falsification of financial reporting. Eining [3], explained that most common type of fraud is made through premature and factious recognition of revenue. Bonner [4], investigated that accounting fraud involves factious transactions and higher litigation against auditors [12].

Marinakis [5], investigated that both earning management and accounting fraud involve common component which is manipulation of financial information for achieving certain results.

Accounting practices wrongly classified comes under fraudulent accounting: Some accounting practices wrongly classified, like back date sale invoice considered fraud intention and it also violates the GAAP and IAS but in some cases back date sale justified the business decision. Like in the case of IAS-11, construction accounts clearly represented the case of legitimate accounting decision by the directors thus; it's not a fraudulent accounting.

Misstated subjectivity of measurement converts into fraudulent accounting: ISA 240 explains that if "subjectivity measurement" misstated then it can postulate fraudulent accounting. Dechow [6], explained that "measurement of subjectivity" is an important factor in auditor books which are used for waiving the decision. Braun [13], investigated that misstatement can be deducted if auditor measure misstatement "subjectively" as opposed to "objectively".

\section{The common ways,companies adopted for earning management and manipulation}

Perols [14], find out that companies do manipulation in earning by inflating revenue; the purpose behind this is to report significant growth. Chen et al. [15], find out that unusual movement in gross margin could because due to earning manipulation.

Summers [16], explored that inventories and account receivables were involved in earning manipulation by $31 \%$ to $61 \%$. Othman 
[17] found that if firms create an inadequate provision for doubtful debts than its impact will affect future earnings (This decreases when provisions will be raised or decreased in future).

Healy [18], drawn a conclusion about depreciation, "reducing accelerating" method to "straight line method' Now this phenomenon is positively correlated with earning management. Bartov E [19] explored that companies do earning manipulation through changing the level of accruals. Duh [20] find out that reversal of previously recognized impairments losses also creates a reason for earning management. Healy [21], find that when companies are close to their dividends managed the earnings by Change in accounting methods (like switching of depreciation method, change of inventory method like FIFO to LIFO,Change in accounting estimates, Use discretionary accruals volatility. Teoh [22], find out that bad debts and depreciations estimations manipulate to increase the income.

Now these strong theoretical backgrounds postulate a research question.

RQ-1 is there any differences between earning management and earning manipulation?

\section{Detection of earning management and earning manipulation}

In other words, detection of earning management based upon accounting accruals. If the accruals are abnormal then we can say that earning management has been postulated.

Abnormal accruals $=$ accounting accruals- expected accruals.

Healy [23], Jones [24], Dechow [25], used aggregate accruals model while Beneish [26], used specific accruals model. Although accruals model has been used in several types of research and numbers of researchers also put a question mark on the accuracy and usefulness of these accruals model.

\section{Detection of earning management can be measured by two approaches}

These approaches are also discussed by Marinakis P [5]. Aggregate Accruals method, Specific Accruals Methods.

Aggregate accrual method approach: Jones [24], introduced this model and later on followed by Kaplan RS [27] by doing some suggestions about the accruals. According to researcher "accruals" are likely outcomes of the exercising managerial "discretions" or may outcome from the "change in firm economic conditions". Researcher used regression model, taken depended on the variable as total accrual and independent variables are sales, property, plant, and equipment. Here sale referred to change in sale and change in the level of property plant and equipment.

Specific accrual method approach: Beneish [28-30], framed that model to measure the financial statements distortions or preconditions. The result of this model defined a systematic relationship between probability of manipulation and specific accruals.

Moyer [31] and Wahlen [8] has explained that banking and insurance companies often use specific accrual methods to managed the earnings like bank creates are serve for loan losses and insurance companies also create the reserve against claim losses. Dechow [31] did more work on Banish model and expand its existing model into a predictive model. This model has scale logistic probability, which indicates that higher values have greater probability of manipulation.

The second objective which has to be achieved is how to develop a more powerful accrual method.
RQ-2. Can we develop a systematic model to measure the earning management and earning manipulation?

\section{The common motives behind the earning management and earning manipulation}

Scholes [32], find out that financial institutes engage in earning management at the time of realization of gain/losses on investment securities.

Beaver [33], conducted a research on property casualty's insurance claim loss reserve. They concluded that this is how earning management takes place among insurers.

Shen [34], find out that companies do earning management to increase the level of earning by using discretionary accrual. Dichev explained the purpose of earning management, it is to avoid losses and meet earning thresholds. Dechow [35], find out that corporate manager has incentives to avoid the reported loss. Gore [36], delivered the findings that firm uses earning management to avoid reporting negative earnings and also to maintain market expectations. Debt covenants' provided incentives for the manager to increase earning by, either way, one by avoiding the cost of covenants and second by violations.

Healy [23], find that when companies are close to their dividends managed the earnings. Guidry [37] find out that divisional manager involved in earning management by doing defer income. Dechow [38], find out that whenever CEO of the firm left with only ten years of their office job than they reduced the R\&D expenses.

Rangan S [39] finds out that magnitude of earning management at the time of equity offering, Beneish [26] conducted a research and make a linkage between financial statement manipulation and inside trading and manager act as informed trader, buying and selling in advance and work for his own benefits.

Dechow [35], find out that higher management of the company usually decreases the spending on R\&D to increase the short-term earnings at the end of accounting period. Roychowdhury [40], find out that management manipulates real activities to reduce the annual reporting losses. Now the rest of two research question is addressing here,

RQ-3 Are firms of BRIC countries involve in earning management and earning manipulation, even after the financial crisis of 2007 to 2010.

RQ- 4 Are firms of BRIC countries are involve in earning manipulation more than earning management, even after the financial crisis of 2007 to 2010 .

\section{Research Design}

Dechow [6], explained that accruals are being used to decrease inconsistencies. These inconsistencies encountered as a result of the difference in timing of the recognition. Beneish [26] furthermore, find out that accruals techniques are less visible. Moreover, it is very much hard to detect and compare with the changing of the real transaction or accounting policies. Thus, accruals open a horizon of opportunities for earning management.

There are two types of Accrual one is called Discretionary accrual and second is called nondiscretionary accrual. The combination of these two accruals is called total accrual. It has been shown in the Figure 1 below: 
Citation: Shahzad A (2016) Detecting Earning Management and Earning Manipulation in BRIC Countries; a Panel Data Analysis for Post Global Financial Crisis Period. Int J Account Res 4: 134. doi:10.4172/2472-114X.1000134

Total Accruals $=$ Non-discretionary accruals + Discretionary Accruals

$$
\downarrow
$$

Imposed on mingement by GAAPIFRS Management ean choose within the flevibility of GAAP/FRS

Figure 1: Discretionary accrual and nondiscretionary accrual.

\section{Rational behind selections of variables}

The variables and model which I have selected, it has been selected by numbers of research already. Different researcher argued that modified Jones model is the powerful model for detecting the earning management.

Sun et al. [41] find out modified Jones model have absolute power to measure earning management. Chen [42] explained in his research methodology that modified Jones model has strong assumptions about its variables. The researcher concluded that modified Jones model is still a good approach to detect earning management. It has more power to explain the earning management as compared to others model. Find out that modified Jones model is a reliable model while measuring earning management. It can also investigate the relationship between managerial share ownership and discretionary accruals.

Islam [43] concluded in his article that modified Jones model is a most powerful tool in detecting and measuring the earning management. Furthermore, Researcher concluded that Jones modified model also works in developed countries like USA, UK, and other countries as well like Malaysia, Taiwan, and India. Alghamdi [44] also concluded those modified Jones models are the most powerful model for detecting the earning management. Cross-sectional modified Jones model performed well in measuring the earning management.

Conceptual framework: Under this heading, I identified my depended and in depended variables and also developed which will be labeled and defined the operationalization of these variables that how these variables work.

Earning management can be deducted with the help of modified Jones model [24]; it has been modified (Figure 2).

Measurement of depended variable: There are two approaches to measuring the total accrual: one is balance sheet approach second is cash flow approach. I will use cash flow approach due to nonarticulation issues.

\section{$\mathrm{TAC} t=$ Income $\mathrm{t}-$ Cash Flow $\mathrm{t}$}

\section{Whereas:}

Income $=$ Earnings before extraordinary and abnormal items in year $\mathrm{t}$

\section{Cash Flow $\mathrm{t}=$ Operating cash flow in year $\mathrm{t}$}

Measurement of independent variables: Several approaches can be used to estimate the nondiscretionary accrual and discretionary accrual (as a proxy of earning management). In this model, I used cross-sectional modified Jones' model to estimate the discretionary and nondiscretionary accrual. Now, we are making a cross-sectional analysis. This model has two stages. Thus, the result of first part of the analysis will plug into next stage to get the estimates which we needed.

First stage model-1 is used to estimate each year using ordinary least squares estimation.

\section{Whereas:}

TA $i t=$ total accruals in year $\mathrm{t}$;

At $i t=$ total assets in year $\mathrm{t}-1$;

ARevit= revenues in year $\mathrm{t}$ fewer revenues in year $\mathrm{t}-1$;

AREC it $=$ net receivables in year $t$ less net receivables in year $\mathrm{t}-1$;

PPE it = gross property plant and equipment in year $t$;

$\boldsymbol{\varepsilon} i t=$ error term in year $\mathrm{t}$, and

á1, $\dot{\alpha} 2$ 2, á3= firm-specific parameters (Estimate the relationship between depended on and in depended variable)

Once coefficients have been estimated then we can utilize these coefficients to estimates non-discretionary accruals. In short, the estimates of a1, a2, and a3 obtained from these regressions are used to estimate non-discretionary accruals as follows:

NDA /A $t-1=$ â $1(1 /$ A $t-1)+$ â2 $(\Delta$ REV $t /$ A $t-1-\Delta$ REC it $) /$ TA $t-1+\hat{a} 3(\operatorname{PPE} t /$ TA $t-1)+\varepsilon t$

$\mathrm{NDA}=$ Non-discretionary Accrual

\section{Development of basic equation for detecting earning management}

As we know total accrual is the composition of discretionary and non-discretionary accruals. Then on discretionary and the nondiscretionary accrual defined the business conditions like the length of operating cycle and growth. These components naturally create and destroy accruals. On the other hand, discretionary accrual components are on the basis of management choice.

In the end, we will extract the discretionary accrual amount from the total accrual amount. In other words, discretionary accrual reflects the accrual which is the result of management choice. Therefore, that accrual represents no business reason to generate this accrual. Thus, for discretionary accrual consider batter proxy for earning management.

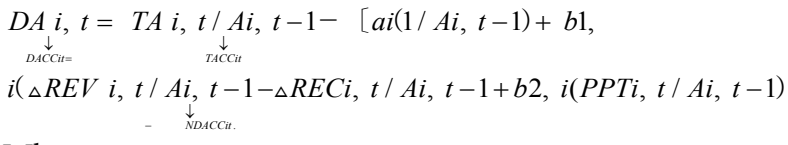

Whereas;

DA= Discretionary accrual (abnormal accrual)

$\mathrm{TA}=$ Total Accrual

NDA = Non-discretionary accruals (expected accrual)

The discretionary-accrual estimates for the firm, it is based on the total accrual. It can be ranked against the discretionary accrual estimates of the firm's peers and all other firms in the sample. This ranking is a comparative measure of the size of discretionary accruals and it is a proxy for the

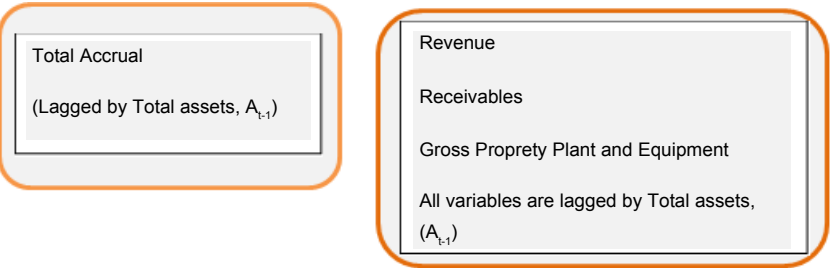

Figure 2: Conceptual framework. 
quality of the firm's earnings. A high amount of discretionary accruals indicates lower-quality earnings and is a red flag that management may be using aggressive accounting to overstate earnings.

\section{Model basic assumption}

The reason behind the cross-sectional Jones model use for analysis is that, it can avoid the biases.

1. It assumes that non-discretionary accruals levels in the same industry are the same.

2. The model can regress the accrual for many firms in the same industry for one time period (cross-sectional) or by regressing accrual data from the same firm across several time periods (time-series)

3. Time-series analysis may not have enough observations in the estimation period to obtain reliable parameter estimates for a linear regression

4. The coefficient estimates on $\triangle$ Sales and GPPE may not be stationary over time.

5. The self-reversing property of accruals may result in serially correlated residuals.

6. If any of these issues above is true, it is impossible to make valid statistical inferences from the regression results obtained with time-series analysis.

7. All variables have been deflated with Lagged(t-1) assets to control the heteroscedasticity because firms are different in size and scale.

8. All the variables are deflated with lagged (t-1) assets. Thus, for we can measure the magnitude of firm discretionary accruals, which indicate the percentage of the total assets of a firm.

Sample selection procedure and sample distribution: The population of my research is based on the BRIC countries (Brazil, Russia, India, and China) companies which are listed on stock market. I have taken as a sample of 50 indexes of stock markets of BRIC countries. For this study exclude the companies which are engaged in construction, mining, banking and financial institutes, to avoid the hyperinflation. For Brazil sample I have taken 32 companies; 28 companies for Russia; 32 companies for India; 27 companies for China and each company's 4 years $(2010,2011,2012$, and 2013) data is taken. The major source of my data collection was company's annual reports.

\section{Analysis tools/method for analysis}

In this Analysis panel data analysis will be applied, whereas panel data deals with individual firms at a time. In panel data analysis heterogeneity found in the companies. Moreover in the panel data time series and cross section observations gives more inferential about the data and produce less collinearity and more variability among variables, thus for generating more efficiency and more degree of freedom. Panel data analysis can detect and measure the effect of variables which cannot do so in the simple cross section and time series analysis. Panel data analysis has the ability to study the complication of the model and overcome the bias results.

In the case of this study, I balanced panel in which numbers of firms have the same number of observation. Whereas, I have short panel data because a number of cross-sectional companies (subject) $\mathrm{N}$ are greater than the number of the time period for each country I have taken 33 companies and each company have 4-year data.
It is the half battle in panel data analysis. Now, rest of battle is about the selection of panel data analysis model which one apply, there are two types of pool data model, each model has own uniqueness and attributes for the application.

1. The fixed effects least squares dummy variables (LSDV) model

2. The random effects model (REM)

The fixed effects least squares dummy variables (LSDV) model: This model allows heterogeneity among firms and allowing them to each company to have its own intercept. This intercept should be changed from one company to another company. It will represent that each company has an own special feature like revenue, receivables and property plant, and equipment basis.

In the FEM (Fixed effect model), each company intercept is time invariant. It remained same over the time (it will not vitiate over time). Thus, for each company slope does not variant over the time (let's say same over a five year)

FEM facilities in pool analysis because when companies pool they neglects the fixed effect, which create bias slope to avoid this issue this model use dummy variable technique which is called (differential intercept dummy technique).

TAC it /Ait- $1=\alpha_{1}+\alpha_{2} D_{2 \mathrm{i}}+\alpha_{3} \mathrm{D}_{3 \mathrm{i}}+\alpha \mathrm{D}+\alpha_{4} \mathrm{D}_{4 i+\ldots \ldots \ldots . .} \alpha_{\mathrm{n} 33} \mathrm{D}_{\mathrm{n} 33}+\gamma 1$ $((\Delta \mathrm{REV}$ it $-\Delta \mathrm{REC}$ it $) / \mathrm{A}$ it-1) $+\gamma 2(\mathrm{PPE}$ it $/ \mathrm{A}$ it -1$)+\varepsilon$ it

Whereas, $\mathrm{D}_{2}=1$ for company 2, 0 otherwise: $\mathrm{D}_{3 \mathrm{i}}$ for company 3,0 otherwise so on with 33 companies.

Now, 32 companies model has introduced only 31 dummy variables. Thus, we can avoid falling into dummy variable trap (it is called perfect collinearity)

The random effect model (REM): This model is unlikely to (LSDV) model, in which each company has own fixed intercept value. But in this model, we assume that intercept values are drawn randomly from the population of the companies (Indexes).

The logic behind this model is: if the dummy variables represent a lack of knowledge about the true model then we can express this ignorance with the help of disturbance term. This approach is called error component model (ECM) or random effect model (REM).

TAC it $/$ A it $-1=\gamma 0(1 / \mathrm{A} i t-1)+\gamma 1((\Delta \mathrm{REV}$ it $-\Delta \mathrm{REC}$ it $) / \mathrm{A} i t-1)+\gamma$ $2(\mathrm{PPE}$ it $/ \mathrm{A}$ it -1$)+\varepsilon$ it

Instead of $\gamma 0$ this fixed we assume that it is random variable

Whereas

TAC it $/ \mathrm{A}$ it $-1=\gamma 0(1 / \mathrm{A} i t-1)+\gamma 1((\Delta \mathrm{REV}$ it $-\Delta \mathrm{REC}$ it $) / \mathrm{A} i t-1)+\gamma$ 2 (PPE it /A it-1) $+\mathrm{W}_{\text {it }}$

This term $\mathrm{W}_{\text {it }}$ represent combined error terms like cross section and time series which is called idiosyncratic because it holds two or more error term. This $\mathrm{W}_{\mathrm{it}}$ is not correlated with any of the explanatory variables which include in the model.

The role of Haussmann test: Now, we will decide that which model will represent our study. It will be based upon the Haussmann test. The null hypothesis under this test reflects that FEM and ECM estimators do not differ substantially. Rejection and acceptance of the null hypothesis will be base upon $x^{2}$ chi-square distribution. If the null hypothesis is rejected, then we can say that ECM is not an appropriate to model because random effects are probably correlates with one or 
Citation: Shahzad A (2016) Detecting Earning Management and Earning Manipulation in BRIC Countries; a Panel Data Analysis for Post Global Financial Crisis Period. Int J Account Res 4: 134. doi:10.4172/2472-114X.1000134

Page 6 of 10

more regressors. So, we can conclude that FEM will be preferred to ECM. Haussmann test inferential is based upon three things; one is chi-square statistic, chi-square degree of freedom and probability value.

\section{Empirical Results}

In the case of this study, the researcher used balanced panel analysis whereas; researcher has short panel data because a number of cross-sectional companies (subject) $\mathrm{N}$ are greater than the number of the time period for each country. Two types of panel data model, each model have owned uniqueness and attributes for the application.

The fixed effects least squares dummy variables (LSDV) model and the random effects model (REM) Model selection based the Hausman test. If the null hypothesis is rejected, then we can say that ECM is not an appropriate model because random effects are probably correlated with one or more regressors. So, we can conclude that FEM will be preferred to ECM.

\section{Hausman test results for Brazil}

The hypothesis underlying the Hausman test is as follows:

Ho: ECM and FEM estimators do not differ substantially

It is clear from the results above that the Hausman test rejects the null hypothesis as the P-value 0.0017 is less than 0.05 ; as a result, we reject the ECM (REM) in favor of FEM.

Now we will consider fixed effect model for analysis interpretation (Table 1).

As the result of Hausman test is in favor of FEM, a table depicts the results of fixed effect regression model or Least Square Dummy Variable (LSDV).

The value of $\mathrm{R}$-squared shows that the independent variables i.e., Discretionary Accruals ((PPE it /Ait-1)) and Non-Discretionary

\begin{tabular}{|c|c|c|c|c|}
\hline Variable & Coefficient & Std. Error & t-Statistic & Prob. \\
\hline C & 0.667046 & 0.205745 & 3.2421 & 0.0019 \\
\hline $\begin{array}{c}\text { (REV/REV(- } \\
\text { 1))-(REC/ } \\
\text { REC(-1))/ } \\
\text { TA(-1) }\end{array}$ & -0.473637 & 0.143428 & -3.302261 & 0.0016 \\
\hline PPE/TA(-1) & -0.756061 & 0.22438 & -3.369561 & 0.0013 \\
\hline \multicolumn{2}{|c|}{ Cross-section fixed (dummy variables) } & \\
\hline $\begin{array}{c}\text { R-squared } \\
\text { Adjusted }\end{array}$ & 0.977052 & Mean dependent var & -0.365339 \\
\hline $\begin{array}{c}\text { R-squared } \\
\text { S.E. of } \\
\text { regression }\end{array}$ & 0.964838 & S.D. dependent var & 1.287763 \\
\hline $\begin{array}{c}\text { Sum squared } \\
\text { resid }\end{array}$ & 3.615267 & Akaike info criterion & 0.267028 \\
\hline \begin{tabular}{c} 
Log likelihood \\
\hline $\begin{array}{c}\text { F-statistic } \\
\text { Prob } \\
\text { (F-statistic) }\end{array}$
\end{tabular} & 21.18265 & 0.000000 & Schwarz criterion & 1.175235 \\
\hline
\end{tabular}

Cross-section random effects test equation:

Dependent Variable: TAC/TA(-1)

Method: Panel Least Squares

Date: 09/19/14 Time: 13:22

Sample (adjusted): 20112013

Periods included: 3

Cross-sections included: 32

Total panel (balanced) observations: 96

Table 1: Fixed effect model-Brazil.
Accruals $((\triangle \mathrm{REV}$ it - $\triangle \mathrm{REC}$ it $) / \mathrm{A}$ it-1)) explain 97\% variations in the dependent variable i.e., Total Accruals (TAC it /A it-1). It also shows the goodness of fit of the LSDV model.

The P-value of the F-statistics is less than 0.05 which shows that the overall model is significant. The value of Durbin-Watson test result shows that there's no autocorrelation among the independent variables of the model.

The regression model discussed in the previous is:

TAC it $/ \mathrm{A}$ it $-1=\gamma 0(1 / \mathrm{A}$ it -1$)+\gamma 1((\Delta \mathrm{REV}$ it $-\Delta \mathrm{REC}$ it $) / \mathrm{A}$ it -1$)+\gamma$ $2(\mathrm{PPE}$ it $/ \mathrm{A}$ it- 1$)+\varepsilon$ it

According to the results of the FEM Brazil, the regression model with the values of intercept and slopes of the independent variables will be as follows:

TAC it $/ \mathrm{A}$ it $-1=0.667046(1 / \mathrm{A}$ it -1$)-0.473637((\Delta \mathrm{REV}$ it $-\Delta \mathrm{REC}$ it)/A it-1) -0.756061 (PPE it /A it-1) + $\varepsilon$ it (12)

As shown in the equation above, the value of constant depicts that if the independent variables are excluded from the equation, the dependent variable i.e., Total Accruals will be equal to 0.667046 . The slope of non-discretionary accruals shows that one unit change in non-discretionary accruals brings 0.473637 units decrease in total accruals. Similarly, the slope of discretionary accruals shows that one unit change in discretionary accruals brings 0.756061 units decrease in total accruals.

As the discretionary accruals are a measure for earning manipulation and non-discretionary accruals are a measure for earning management, it is clear that the selected set of companies in Brazil is involved in earning manipulation more than earning management.

\section{Hausman test results for Russia}

\section{Ho: ECM and FEM estimators do not differ substantially}

It is clear from the results above that the Hausman test accepts the null hypothesis as the P-value 0.7461 is more than 0.05 ; as a result, we accept the ECM (REM) against FEM.

Now we will consider Random effect model for analysis interpretation (Table 2).

As the result of Hausman test is in favor of REM, depicts the results of random effect model. The value of $\mathrm{R}$-squared shows that the independent variables i.e., Discretionary Accruals ((PPE it /Ait-1)) and Non-Discretionary Accruals ( $(\triangle \mathrm{REV}$ it - $\triangle \mathrm{REC}$ it $) / \mathrm{A}$ it-1)) explain $2.9 \%$ variations in the dependent variable i.e., Total Accruals (TAC it /A it1). It also shows the goodness of fit of the REM model. The P-value of the F-statistics is more than 0.05 which shows that the overall model is insignificant. The value of Durbin-Watson test result shows that there's is no autocorrelation among the independent variables of the model.

The regression model discussed in the previous is:

TAC it $/ \mathrm{A}$ it $-1=\gamma 0(1 / \mathrm{A}$ it -1$)+\gamma 1((\Delta \mathrm{REV}$ it $-\Delta \mathrm{REC}$ it $) / \mathrm{A}$ it -1$)+\gamma$ $2(\mathrm{PPE}$ it /A it-1) $+\varepsilon$ it

According to the results of the REM Russia, the regression model with the values of intercept and slopes of the independent variables will be as follows:

TAC it /A it-1=12.01824(1/A it-1) - 4.007961(( $\triangle \mathrm{REV}$ it $-\Delta \mathrm{REC}$ it)/A it-1) -6.935018 (PPE it /A it-1) $+\varepsilon$ it 
Citation: Shahzad A (2016) Detecting Earning Management and Earning Manipulation in BRIC Countries; a Panel Data Analysis for Post Global Financial Crisis Period. Int J Account Res 4: 134. doi:10.4172/2472-114X.1000134

\begin{tabular}{|c|c|c|c|c|}
\hline Variable & Coefficient & Std. Error & t-Statistic & Prob. \\
\hline C & 12.01824 & 9.270711 & 1.296366 & 0.1986 \\
\hline $\begin{array}{c}(\operatorname{REV} / \operatorname{REV}(-1))- \\
(\operatorname{REC} / \operatorname{REC}(-1)) / \\
\operatorname{TA}(-1)\end{array}$ & -4.007961 & 7.288674 & -0.549889 & 0.5839 \\
\hline PPE/TA(-1) & -6.935018 & 5.095079 & -1.361121 & 0.1773 \\
\hline \multicolumn{5}{|c|}{ Effects Specification } \\
\hline & & & S.D. & Rho \\
\hline \multicolumn{3}{|c|}{ Cross-section random } & 0 & 0 \\
\hline \multicolumn{3}{|c|}{ Idiosyncratic random } & 15.92487 & 1 \\
\hline \multicolumn{5}{|c|}{ Weighted Statistics } \\
\hline R-squared & 0.029214 & \multicolumn{2}{|c|}{ Mean dependent var } & 1.661652 \\
\hline $\begin{array}{l}\text { Adjusted } \\
\text { R-squared }\end{array}$ & 0.004945 & \multicolumn{2}{|c|}{ S.D. dependent var } & 15.66498 \\
\hline $\begin{array}{l}\text { S.E. of } \\
\text { regression }\end{array}$ & 15.6262 & \multicolumn{2}{|c|}{ Sum squared resid } & 19534.25 \\
\hline F-statistic & 1.203745 & \multicolumn{2}{|c|}{ Durbin-Watson stat } & 1.554592 \\
\hline Prob(F-statistic) & 0.305444 & & & \\
\hline \multicolumn{5}{|c|}{ Unweighted Statistics } \\
\hline R-squared & 0.029214 & \multicolumn{2}{|c|}{ Mean dependent var } & 1.661652 \\
\hline $\begin{array}{l}\text { Sum squared } \\
\text { resid }\end{array}$ & 19534.25 & \multicolumn{2}{|c|}{ Durbin-Watson stat } & 1.554592 \\
\hline
\end{tabular}

Dependent Variable: TAC/TA(-1)

Method: Panel EGLS (Cross-section random effects)

Date: 09/19/14 Time: 15:53

Sample (adjusted): 20112013

Periods included: 3

Cross-sections included: 28

Total panel (unbalanced) observations: 83

Swamy and Arora estimator of component variances

Table 2: Random effect model-Russia.

As shown in the equation above, the value of constant depicts that if the independent variables are excluded from the equation, the dependent variable i.e., Total Accruals will be equal to 12.01824. The slope of non-discretionary accruals shows that one unit change in non-discretionary accruals brings - 4.007961units decrease in total accruals. Similarly, the slope of discretionary accruals shows that one unit change in discretionary accruals brings -6.935018 units decrease in total accruals.

As the discretionary accruals are a measure for earning manipulation and non-discretionary accruals are a measure for earning management, it is clear that the selected set of companies in Russia are involved in earning manipulation more than earning management but as discuss earlier that model is insignificant and independent variables do not explain significant variation in the dependent variable.

Following are showing the detailed results of data analysis for India.

\section{The Hausman test results for India}

Ho: ECM and FEM estimators do not differ substantially.

It is clear from the results above that the Hausman test rejects the null hypothesis as the P-value 0.0014 is less than 0.05 ; as a result, we reject the ECM (REM) in favor of FEM.

Now we will consider fixed effect model for analysis interpretation (Table 3).

As the result of Hausman test is in favor of FEM, table depicts the results of fixed effect regression model or Least Square Dummy Variable (LSDV).

The value of $\mathrm{R}$-squared shows that the independent variables i.e., Discretionary Accruals ((PPE it /Ait-1)) and Non-Discretionary
Accruals $((\triangle \mathrm{REV}$ it - $\triangle \mathrm{REC}$ it $) / \mathrm{A}$ it-1)) explain $80 \%$ variations in the dependent variable i.e., Total Accruals (TAC it /A it-1). It also shows the goodness of fit of the LSDV model. The P-value of the F-statistics is less than 0.05 which shows that the overall model is significant. The value of Durbin-Watson test result shows that there's no autocorrelation among the independent variables of the model.

The regression model discussed in the previous is:

TAC it $/ \mathrm{A}$ it $-1=\gamma 0(1 / \mathrm{A}$ it -1$)+\gamma 1((\Delta \mathrm{REV}$ it $-\Delta \mathrm{REC}$ it $) / \mathrm{A}$ it -1$)+\gamma$ $2(\mathrm{PPE}$ it $/ \mathrm{A}$ it -1$)+\varepsilon$ it

According to the results of the FEM India, the regression model with the values of intercept and slopes of the independent variables will be as follows:

TAC it $/ \mathrm{A}$ it $-1=-0.075482(1 / \mathrm{A}$ it- 1$)+0.020563((\Delta \mathrm{REV}$ it $-\Delta \mathrm{REC}$ it)/A it-1) + $0.039094(\mathrm{PPE}$ it /A it-1) $+\varepsilon$ it

As shown in the equation above, the value of constant depicts that if the independent variables are excluded from the equation, the dependent variable i.e., Total Accruals will be equal to -0.075482 . The slope of nondiscretionary accruals shows that one unit change in non-discretionary accruals brings 0.020563 units increase in total accruals. Similarly, the slope of discretionary accruals shows that one unit change in discretionary accruals brings 0.039094 units increase in total accruals.

As the discretionary accruals are a measure for earning manipulation and non-discretionary accruals are a measure for earning management, it is clear that the selected set of companies in India is involved in earning manipulation more than earning management.

Following are showing the detailed results of data analysis for China.

\section{The Hausman test results for China}

Ho: ECM and FEM estimators do not differ substantially.

It is clear from the results above that the Hausman test accepts the null hypothesis as the P-value 0.3190 is more than 0.05 ; as a result, we accept the ECM (REM) against FEM.

\begin{tabular}{|c|c|c|c|c|}
\hline Variable & Coefficient & Std. Error & t-Statistic & Prob. \\
\hline $\mathrm{C}$ & -0.075482 & 0.064331 & -1.173336 & 0.2451 \\
\hline $\begin{array}{c}(\mathrm{REV} / \mathrm{REV}(-1))- \\
(\mathrm{REC} / \mathrm{REC}(-1)) / \\
\mathrm{TA}(-1)\end{array}$ & 0.020563 & 0.013091 & 1.570749 & 0.1213 \\
\hline PPE/TA(-1) & 0.039094 & 0.0759 & 0.515068 & 0.6083 \\
\hline \multicolumn{5}{|c|}{ Effects Specification } \\
\hline \multicolumn{5}{|c|}{ Cross-section fixed (dummy variables) } \\
\hline R-squared & 0.801101 & \multicolumn{2}{|c|}{ Mean dependent var } & -0.018546 \\
\hline $\begin{array}{l}\text { Adjusted } \\
\text { R-squared }\end{array}$ & 0.695236 & \multicolumn{2}{|c|}{ S.D. dependent var } & 0.097185 \\
\hline $\begin{array}{l}\text { S.E. of } \\
\text { regression }\end{array}$ & 0.053651 & \multicolumn{2}{|c|}{ Akaike info criterion } & -2.741505 \\
\hline $\begin{array}{l}\text { Sum squared } \\
\text { resid }\end{array}$ & 0.178464 & \multicolumn{2}{|c|}{ Schwarz criterion } & -1.833299 \\
\hline Log likelihood & 165.5923 & Hannan- & criteria & -2.374393 \\
\hline F-statistic & 7.567169 & \multicolumn{2}{|c|}{ Durbin-Watson stat } & 2.526443 \\
\hline Prob(F-statistic) & 0.000000 & & & \\
\hline
\end{tabular}

Cross-section random effects test equation:

Dependent Variable: TAC/TA(-1)

Method: Panel Least Squares

Date: 09/17/14 Time: 17:50

Sample (adjusted): 20112013

Periods included: 3

Cross-sections included: 32

Total panel (balanced) observations: 96

Table 3: Fixed effect model-India. 
Now we will consider Random effect model for analysis interpretation (Table 4).

As the result of Hausman test is in favor of REM, depicts the results of random effect model. The value of R-squared shows that the independent variables i.e., Discretionary Accruals ((PPE it /Ait-1)) and Non-Discretionary Accruals (( $\triangle \mathrm{REV}$ it - $\triangle \mathrm{REC}$ it $) / \mathrm{A}$ it-1)) explain $32 \%$ variations in the dependent variable i.e., Total Accruals (TAC it /A it1). It also shows the goodness of fit of the REM model. The P-value of the F-statistics is less than 0.05 which shows that the overall model is significant. The value of Durbin-Watson test result shows that there's is autocorrelation among the independent variables of the model.

The regression model discussed in the previous is:

TAC it $/ \mathrm{A}$ it $-1=\gamma 0(1 / \mathrm{A}$ it -1$)+\gamma 1((\Delta \mathrm{REV}$ it $-\Delta \mathrm{REC}$ it $) / \mathrm{A} i t-1)+\gamma$ $2(\mathrm{PPE}$ it $/ \mathrm{A}$ it -1$)+\varepsilon$ it

According to the results of the REM China, the regression model with the values of intercept and slopes of the independent variables will be as follows:

TAC it $/ \mathrm{A}$ it $-1=--0.066512(1 / \mathrm{A}$ it -1$)+0.157072((\Delta \mathrm{REV}$ it $-\Delta \mathrm{REC}$ it)/A it-1) -0.200756 (PPE it /A it-1) + $\varepsilon$ it

As shown in the equation above, the value of constant depicts that if the independent variables are excluded from the equation, the dependent variable i.e., Total Accruals will be equal to -0.075482 . The slope of non-discretionary accruals shows that one unit change in non-discretionary accruals brings 0.157072 units increase in total accruals. Similarly, the slope of discretionary accruals shows that one unit change in discretionary accruals brings -0.200756 units decrease in total accruals.

\begin{tabular}{|c|c|c|c|c|}
\hline Variable & Coefficient & Std. Error & t-Statistic & Prob. \\
\hline $\mathrm{C}$ & -0.066512 & 0.026746 & -2.486799 & 0.015 \\
\hline $\begin{array}{c}(\operatorname{REV} / \operatorname{REV}(-1))- \\
(\operatorname{REC} / \operatorname{REC}(-1)) / \\
\operatorname{TA}(-1)\end{array}$ & 0.157072 & 0.02726 & 5.761912 & 0 \\
\hline PPE/TA(-1) & -0.200756 & 0.047376 & -4.237465 & 0.0001 \\
\hline \multicolumn{5}{|c|}{ Effects Specification } \\
\hline & & & S.D. & Rho \\
\hline \multicolumn{3}{|c|}{ Cross-section random } & 0.065624 & 0.761 \\
\hline \multicolumn{3}{|c|}{ Idiosyncratic random } & 0.036774 & 0.239 \\
\hline \multicolumn{5}{|c|}{ Weighted Statistics } \\
\hline R-squared & 0.327104 & \multicolumn{2}{|c|}{ Mean dependent var } & -0.007946 \\
\hline $\begin{array}{l}\text { Adjusted } \\
\text { R-squared }\end{array}$ & 0.30985 & \multicolumn{2}{|c|}{ S.D. dependent var } & 0.044347 \\
\hline $\begin{array}{l}\text { S.E. of } \\
\text { regression }\end{array}$ & 0.036841 & \multicolumn{2}{|c|}{ Sum squared resid } & 0.105869 \\
\hline F-statistic & 18.95843 & \multicolumn{2}{|c|}{ Durbin-Watson stat } & 1.813479 \\
\hline Prob(F-statistic) & 0.000000 & & & \\
\hline \multicolumn{5}{|c|}{ Unweighted Statistics } \\
\hline R-squared & 0.146276 & \multicolumn{2}{|c|}{ Mean dependent var } & -0.025812 \\
\hline $\begin{array}{l}\text { Sum squared } \\
\text { resid }\end{array}$ & 0.435115 & \multicolumn{2}{|c|}{ Durbin-Watson stat } & 0.441242 \\
\hline
\end{tabular}

Dependent Variable: TAC/TA(-1)

Method: Panel EGLS (Cross-section random effects)

Date: 09/19/14 Time: 16:04

Sample (adjusted): 20102012

Periods included: 3

Cross-sections included: 27

Total panel (balanced) observations: 81

Swamy and Arora estimator of component variances

Table 4: Random effect model-China.
As the discretionary accruals are a measure for earning manipulation and non-discretionary accruals are a measure for earning management, it is clear that the selected set of companies in China is involved in earning manipulation more than earning management.

\section{Summary and Conclusions}

Now after the extensive data analysis, it has been clear that user of the financial statement overlooks the some aspects of the financial statement which provides some information about the quality of firms reported its earnings. My study has clearly developed a model and can assist the user of financial statement how much can be trusted on the reported result and companies management how much made manipulation in their financial statement [45].

Although it has been clear that analysis would not give you a definitive thumbs up and thumbs down results due to it some limitation in model specification and availability of data, but it will enable the user of financial statements to understand the risk of earning management and earning manipulation involve in firms reported earnings. In this study, I have discussed in the detail key issues involve in the quality of earning and why firms incline towards for earning management and earning manipulation. The study also concludes that earning quality will vary on the basis of following GAAP and IASB practices. If manager follows the practice with great intention then there are fewer chances of earning manipulation. Moreover, one thing also clears that not every signal of change in accounting policy and accruals will consider earning manipulation. Only aggressive accrual will be considered as earning manipulation.

Now it has been clear from the result that Brazil involves in earning manipulation as compared to earning management. The reason behind the earning manipulation is weak corporate governance structure. This structure could not able to implement GAAP or IASB properly on companies across the board. In every country companies corporate governance structure is regulated through security exchange commission board, it mean in Brazil have weak security exchange commission which could not able to exercise its authority.

In Case of Russia, the model could not be able to detect the significant earning manipulation; one reason behind this issue is that Russian company's data collection are very limited. In this particular study, the variables use in the model is unable to detect the earning management and earning manipulation in Russian Companies. Most of the Russian companies do not follow the IASB or GAAP rather they follow own country GAAPs. Russia has faced an economic downturn in 2010, and new technology was also introduced in the same year; one of being these reasons for high impairment losses shown in financial statements of data derived from Russian economy. It has also been observing that there were huge disposal losses faced by the organization, this is another reason the data being distorted.

In the Case of India, companies very much involve in earning manipulation as compared to earning management. Reason Behind is the same weak Corporate Governance structure. The security exchange commission could not apprehend several financial schemes during the last decade. List of the scheme is in the appendixes.

In the Case of china, companies are involved in earning manipulation due to non-adoption of IASB or GAAP. Chinese companies' uses own format (Local GAAP) for presenting the financial statements. A Foreign investor cannot invest in Blue chip companies of the China; it might provide a cover to the user of the financial statement for manipulation. 
Citation: Shahzad A (2016) Detecting Earning Management and Earning Manipulation in BRIC Countries; a Panel Data Analysis for Post Global Financial Crisis Period. Int J Account Res 4: 134. doi:10.4172/2472-114X.1000134

Fraud detection in the financial statement is the front end burner. There are a huge scheme and billions of losses behind the renowned companies like Tyco, Enron, and WorldCom. After the financial crisis number of fraud scheme has slowed but not stop.

According to the report by "Certified Fraud Examiner" stated that only $3 \%$ of frauds detected by audit committee and $7 \%$ of frauds detected by accidently. Furthermore, $82 \%$ of fraudsters had never previously been punished. CFE reviewed and stated that $92 \%$ cases found common behavior; red flags were identified before the fraud detection. Auditors and others should be trained to recognize these warning signs that, when combined with other factors, might indicate fraud. If the user of financial statement is intent to determine the earning quality in reported financial statements, the user of financial statements must consider the factors that effect from the outside financial reporting system; user of financial statement must also have ability to identify the types of accounts which played a major role in earning manipulation. The user of the financial statement must be aware of which type of account can easily manipulate. It must be able to judge the circumstances of companies in which management mostly involve in earning manipulation.

There is another responsibility require from accounting standard bodies like, IASB or GAAPs that they should reduce the role of discretionary accruals. By developing and revising the accounting standard, Although most of the accounting standards are being revised with that consent, but there is still more room available in the Accounting standard for discretionary accrual, which should be minimized or eliminated, by implementing these recommendations, earning management and earning manipulation can be controlled.

\section{Referneces}

1. Levitt $A$ (1998) The numbers game. The CPA Journal 68: 14-19.

2. Schipper K (1989) Commentary on earnings management. Accounting Horizons 3: 91-102.

3. Eining MM, Jones DR, Loebbecke JK (1997) Reliance on decision aids: An examination of auditors assessment of management fraud. Auditing: A Journal of Practice \& Theory.

4. Bonner SE, Palmrose ZV, Young SM (1998) Fraud type and auditor litigation: An analysis of SEC accounting and auditing enforcement releases. Accounting Review pp: 503-532.

5. Marinakis $P$ (2011) An investigation of earnings management and earnings manipulation in the UK. University of Nottingham.

6. Dechow PM, Skinner DJ (2000) Earnings management: Reconciling the views of accounting academics, practitioners, and regulators. Accounting Horizons 14: $235-250$

7. Rosner RL (2003) Earnings manipulation in failing firms. Contemporary Accounting Research 20: 361.

8. Wahlen JM (1994) The nature of information in commercial bank loan loss disclosures. Accounting Review pp: 455-478

9. Athanasakou VE, Strong NC, Walker M (2009) Earnings management or forecast guidance to meet analyst expectations? Accounting and Business Research 39: 3-35.

10. Hodge FD (2003) Investors perceptions of earnings quality, auditor independence, and the usefulness of audited financial information. Accounting Horizons 17: 37-48.

11. Karamanou I, Vafeas $\mathrm{N}$ (2005) The association between corporate boards, audit committees, and management earnings forecasts: An empirical analysis. Journal of Accounting research 43: 453-486.

12. Becker CL, DeFond ML, Jiambalvo J, Subramanyam KR (1998) The effect of audit quality on earnings management. International Reviews of Immunology 16: 1-24.
13. Braun KW (2001) The disposition of audit-detected misstatements: an examination of risk and reward factors and aggregation effects. Contemporary Accounting Research 18: 71-99.

14. Perols JL, Lougee BA (2011) The relation between earnings management and financial statement fraud. Advances in Accounting 27: 39-53.

15. Chen C, Sennetti J (2005) Fraudulent financial reporting characteristics of the computer industry under a strategic-systems lens. Journal of Forensic Accounting 6: 23-54.

16. Summers SL, Sweeney JT (1998) Fraudulently misstated financial statements and insider trading: an empirical analysis. Accounting Review pp: 131-146.

17. Othman HB, Zeghal D (2006) A study of earnings-management motives in the Anglo-American and Euro-Continental accounting models: The Canadian and French cases. The International Journal of Accounting 41: 406-435.

18. Healy PM, Kang SH, Palepu KG (1987) The effect of accounting procedure changes on CEOs' cash salary and bonus compensation. Journal of accounting and economics 9: 7-34.

19. Bartov E, Cohen DA (2009) The "Numbers Game" in the pre-and postSarbanes-Oxley eras. Journal of Accounting, Auditing \& Finance 24: 505-534.

20. Duh RR, Lee WC, Hua CY (2009) Non-audit service and auditor independence: an examination of the Procomp effect. Review of Quantitative Finance and Accounting 32: 33-59.

21. Healy PM, Palepu KG (1993) The effect of firms financial disclosure strategies on stock prices. Accounting Horizons 7: 1-11.

22. Teoh SH, Welch I, Wong TJ (1998) Earnings management and the long-run market performance of initial public offerings. The Journal of Finance 53: 1935 1974

23. Healy PM (1985) The effect of bonus schemes on accounting decisions Journal of accounting and economics 7: 85-107.

24. Jones J (1991) Earnings management during import relief investigations Journal of Accounting research 29: 193-228.

25. Dechow PM, Sloan RG, Sweeney AP (1995) Detecting earnings management. Accounting Review pp: 193-225.

26. Beneish MD (1999) The detection of earnings manipulation. Financial Analysts Journal pp: 24-36

27. Kaplan RS (1985) Evidence on the effect of bonus schemes on accounting procedure and accrual decisions. Journal of accounting and economics 7: 109-113.

28. Beneish MD (1997) Detecting GAAP violation: Implications for assessing earnings management among firms with extreme financial performance. Journal of Accounting and Public Policy 16: 271-309.

29. Beneish MD (1998) Discussion of "Are accruals during initial public offerings opportunistic?". Review of accounting studies 3: 209-221.

30. Moyer SE (1990) Capital adequacy ratio regulations and accounting choices in commercial banks. Journal of accounting and economics 13: 123-154.

31. Dechow PM, Dichev ID (2002) The quality of accruals and earnings: The role of accrual estimation errors. The accounting review 77: 35-59.

32. Scholes MS, Wilson GP, Wolfson MA (1990) Tax planning, regulatory capital planning, and financial reporting strategy for commercial banks. Review of financial Studies 3: 625-650.

33. Beaver WH, McNichols MF, Nelson KK (2003) Management of the loss reserves accrual and the distribution of earnings in the property-casualty insurance industry. Journal of accounting and economics 35: 347-376.

34. Shen $\mathrm{CH}$, Chih $\mathrm{HL}$ (2005) Investor protection, prospect theory, and earnings management: An international comparison of the banking industry. Journal of Banking \& Finance 29: 2675-2697.

35. Dechow PM, Sloan RG (1991) Executive incentives and the horizon problem An empirical investigation. Journal of accounting and economics 14: 51-89.

36. Gore P, Pope PF, Singh AK (2007) Earnings management and the distribution of earnings relative to targets: UK evidence. Accounting and Business Research 37: 123-149.

37. Guidry FJ, Leone A, Rock S (1999) Earnings-based bonus plans and earnings management by business-unit managers. Journal of accounting and economics 26: 113-142. 
Citation: Shahzad A (2016) Detecting Earning Management and Earning Manipulation in BRIC Countries; a Panel Data Analysis for Post Global Financial Crisis Period. Int J Account Res 4: 134. doi:10.4172/2472-114X.1000134

38. Dechow PM, Sloan RG, Sweeney AP (1996) Causes and consequences of earnings manipulation: an analysis of firms subject to enforcement by the SEC. Contemporary Accounting Research 13: 1-36.

39. Rangan S (1998) Earnings management and the performance of seasoned equity offerings. Journal of Financial Economics 50: 101-122.

40. Roychowdhury S (2006) Earnings management through real activities manipulation. Journal of accounting and economics 42: 335-370.

41. Sun L, S Rath (2011) The effect of firm performance on modeling discretionary accruals: an evaluation of accrual models. Proceedings of Macao International Symposium on Accounting and Finance.
42. Chen T (2012) Analysis on accrual-based models in detecting earnings management. Lingnan Journal of Banking, Finance and Economics 2: 5

43. Islam MAR (2014) Is modified Jones model effective in detecting earnings management? Evidence from a developing economy. International Journal of Economics and Finance 3: 116

44. Alghamdi S, Ali L (2012) The investigation into earnings management practices and the role of corporate governance and external audit in emerging markets. Empirical evidence from Saudi listed companies, Durham University.

45. Defond ML, Subramanyam KR (1998) Auditor changes and discretionary accruals. Journal of accounting and Economics 25: 35-67. 